\title{
1011 トランスレーショナルリサーチ(21)
}

創 薬

シリーズ(5)

\section{新規抗がん薬の \\ 創製プロセスとトランスレーショナルリサーチ}

要約：医薬品開発の成功確率は 10,000 分の 1 以下と 低く，要する年数は 10 年以上である. 投資する研究 開発の金額は 100 億円超と言われており，この成功確 率を高めることは重要である。この課題を解決するた めの 1 つの手法として,「トランスレーショナルリサ 一チ」の重要性が高まっており, 研究成果の実用化, 成功確率を高めるための様々な試みがなされてきてい る. 本稿では, 新規抗がん薬, 特に「がん分子標的薬」 の創製プロセスに拈ける「トランスレーショナルリサ 一チ」の果たす役割について概説する.

\section{はじめに}

厚生労働省の統計では，がんによる死亡者数は年間 33 万 6,468 人に達している. 死因の $30.4 \%$ を占め, 「日本人の 3 人に 1 人ががんで死亡する」ことが報告 されている (平成 19 年). また, 平成 15 年の罹患数も 64 万 1,594 人と生涯リスクとして,「日本人の 2 人に 1 人ががんになる」と推定されている，既にがん受療・ 患者数は 142 万人に達しており, その医療費は 2 兆 6,958 億円であり一般診療費全体の $10.5 \%$ を占めてい る。国立がんセンターの調査では,「男女とも, がんの 死亡数は増加し続けている. 2008 年のがん死亡数は, 1975 年の約 2.5 倍. がん死亡数の増加の主な原因は人 口の高齢化」とされている.このため, 今後もがん患 者の増加が見达まれ，その対策が急務である(1).

一方，20世紀末〜21 世紀にかけて多くの新規抗が ん薬が臨床試験へ進んだ。過去 10 年間に新たに承認 されてきた抗がん薬の多くは, 新規メカニズムで有効 性を示す分子標的薬に分類される. さらに, 様々な標 的に対する分子標的抗がん薬の新薬候補が臨床試験へ 進みつつある。しかしながら臨床試験入りした化合物 が上市される成功確率は $10 \%$ 以下と低い。この課題 を克服するための 1 つの解決策として, トランスレー ショナルリサーチの重要性が高まっている，以下， (1) がん分子標的の分類，(2)新規分子標的抗がん薬の創製 プロセスとトランスレーショナルリサーチについて概
説し, (3)今後の課題についても言及する.

\section{1. がん分子標的の分類}

がん分子標的薬の研究開発における最初のステップ は, 標的分子の (再) 発見とその機能解析である. 標 的とする分子によって, 適応がん種も創薬プロセスも 全く異なるため, 標的分子の選定は最も重要なプロセ スの 1 つである. 2000 年の Cell 誌で米国の Hanahan 博士と Weinberg 博士が提示した“がんの特徴（The Hallmarks of Cancer)” では, 腫瘍形成に必要な要素と して“無制限の複製能力 (limitless replicative potential)”, “持続的血管新生 (sustained angiogenesis)”, “アポト ーシスの回避 (evading apoptosis)”, “増殖シグナルの 自給 (self-sufficiency in growth signals)”, “抗増殖 シグナルへの非感受性（insensitivity to anti-growth signals)”そして“組織浸潤と転移 (tissue invasion \& metastasis)”の6つが挙げられている (2). 本稿では 以下の 3 項目について具体例として取り上げる.

最初に取り上げる分子標的は,「がん遺伝子」と「が ん抑制遺伝子」で“無制限の複製能力 (limitless replicative potential)”に関わる因子と考えられている。 1970 80 年代のがん研究では ras や myc などの「がん 遺伝子」, p53や Rbなどの「がん抑制遺伝子」の発見 が相次ぎ, 遺伝子変異や遺伝子欠損によって発がんす ることが実験的に示された。そして変異 ras 遺伝子を 正常細胞に導入することにより, 腫瘍が形成されるこ とが明らかになり，がん遺伝子である rasに対する阻 害薬研究が世界中で盛んに行われた。また，がん抑制 遺伝子である 553 の変異による腫瘍形成も報告され, p53 機能を修復する創薬が行われてきた。これら ras や p53に対する研究は非常に長い歴史を持っているが, 残念ながら rasを直接阻害する抗がん薬, あるいはp53 へ直接作用する抗がん薬は未だ無い.

次に腫瘍血管，“持続的血管新生 (sustained angiogenesis)”に関わる分子標的ついて取り上げる. 1970 年代に腫瘍における血管新生の概念が提案され

キーワード：がん分子標的薬, トランスレーショナルリサーチ, バイオマーカー

協和発酵キリン株式会社 研究本部（テ194-8533 東京都町田市旭町 3-6-6)

E-mail: yukimasa.shiotsu@kyowa-kirin.co.jp＼cjkstart原稿受領日：2011 年 2 月 4 日，依頼原稿

Title: Molecular target therapeutics of cancer and translational research. Author: Yukimasa Shiotsu 
て以来, VEGF, PDGR, FGF, アンジオポエチン (angiopoietin), HGF, IL-8 な゙の多くの因子が関与 することが明らかにされてきた，中でもVEGFとその 受容体キナーゼである KDR（VEGF-R2）は腫瘍血管 の新生に重要な役割をしている，VEGFに対する中和 抗体や KDRに対するキナーゼ阻害薬は, 多くの前臨 床試験（主にマウス皮下にヒト腫瘍を移植した xenograft モデル) で有効性を示し, 数十以上の新薬候 補化合物が臨床試験へ進んできた，腫瘍における血管 新生の概念が提案されてから約 30 年以上の年月を経 て, これまでに米国食品医薬局（FDA）に承認されて いる血管新生阻害薬は, VEGF に対する中和抗体べバ シズマブ (bevacizumab: 大腸がん), KDR 阻害作用を 有するソラフェニブ (sorafenib: 腎細胞がん, 肝細胞が ん), スニチニブ (sunitinib: 腎細胞がん), パゾパニブ (pazopanib: 腎細胞がん), エベロリムス (everolimus: 腎細胞がん）の 5 郕になっている.

3 番目に取り上げる分子標的はキナーゼ経路に代表 される“増殖シグナルの自給 (self-sufficiency in growth signals)”である. がん細胞では, 受容体型キ ナーゼや染色体転座で生成したキナーゼが恒常的に活 性化することにより，シグナル経路が刺激され増殖シ グナルが流れると考えられている. シグナル経路にあ る分子の代表例として EGFR (epidermal growth factor receptor) ファミリーが挙げられる. EGFRは別名 erbB1, HER1 としても知られており, 多くの腫瘍細胞 で過剩発現が報告されている。 また EGFRに構造的に 類似した HER2（別名 EGFR2, ERBB2，あるいは NEU) はそのリガンドは不明であるが，乳がんをはじ めとして多くの腫瘍での過剩発現が報告されてきた.

これら EGFRファミリーは 1980 年代の半ばに発見さ れた分子である。その阻害薬として抗 HER2 抗体であ るトラスッズマブ (trastuzumab: 乳がん), 抗 EGFR抗 体であるセツキシマブ (cetuximab: 大腸がん, 頭頸部 がん), EGFR キナーゼに対する低分子阻害薬である ゲフィニチブ (gefitinib), エルロチニブ (erlotinib: 非 小細胞肺がん）が承認されてきた。

紙面の都合上, 本稿では取り上げていないが, 先述 の “がんの特徵 (The Hallmarks of Cancer)”で取り上 げている, アポトーシス, 浸潤・転移, 治療不応答な どに関する分子群も徐々に明らかにされている。いま は, 新規がん分子標的としての価值が見極められてい る状況である. 1980 90 年代には分子生物学が急速 に進展し, 2001 年にはヒトゲノムの全貌が明らかにな った。この間, がんで発現立進や欠損している分子群 が続々と明らかにされ，遺伝子情報の変化によりがん が形成されることが実験的にも明らかにされてきた。 さらに次世代シークエンサーの登場により大量の塩基 配列を極めて短時間で解析することが可能となり, ゲ ノム情報の変化とがんの新たな関係が明らかにされて きた。また，ゲノム解析で明らかにされてきた遺伝子

情報だけでなく，ゲノムの化学修飾が遺伝子発現を制 御している機構が明らかにされつつある。このような 研究は, エピゲノム研究として注目を集めている.

\section{2. がん分子標的治療薬の創製プロセスにおける トランスレーショナルリサーチ}

\section{1）トランスレーショナルリサーチ}

「トランスレーショナルリサーチ」の意味を一言で 表すと, 基礎研究の成果を臨床現場で実用化させるた めの橋渡し研究である。もう少し具体的に表すと, 大 学・研究機関・ベンチャー企業での基礎研究から派生 する創薬シーズ・創薬技術, さらには新規化合物を,

医薬品として事業化するための一連の橋渡し研究を指 している. Googleで「translational research」を検索 すると 263 万件のヒットを超え,「トランスレーショ ナルリサーチ」で検索すると, 18,000 件以上のヒット が得られる. 非常に多くの意味や分野で「トランスレ ーショナルリサーチ」という言葉が使われてきている のが判る.

一方, 現在, 臨床現場で使用されている多くの抗が ん薬は大まかに, がん細胞を死滅させることを主目的 として研究開発されてきた「従来型の抗がん薬」と, がん細胞や腫瘍環境で発現や機能が更新している標的 に対して作用する「がん分子標的治療薬」に二分する ことができる。その創製プロセスの違いを示したのが 図 1 である.「従来型の抗がん薬」は in vitro と in vivo で細胞死滅させる作用を主薬効としている。これに対 し,「がん分子標的治療薬」は, 標的分子探索からはじ まり，標的分子に対し作用する化合物を探索するとい う創製プロセスを経る．両者の対比を示したのが図 2 である。

先述のとおり, 近年の目覚しい学問の進展と技術の 進歩により，がんに関わる分子が次々と明らかにされ， 標的分子に作用する新規がん分子標的治療薬が承認さ

\section{従来型の抗がん薬}

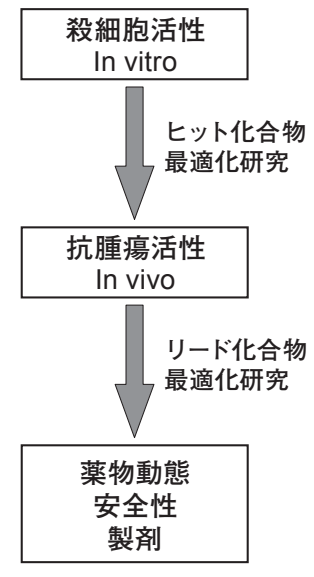

がん分子標的治療薬

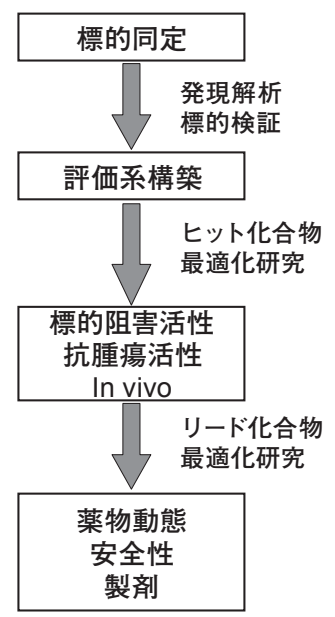

図 1 従来型の抗がん薬とがん分子標的治療薬のプロセスの比較 


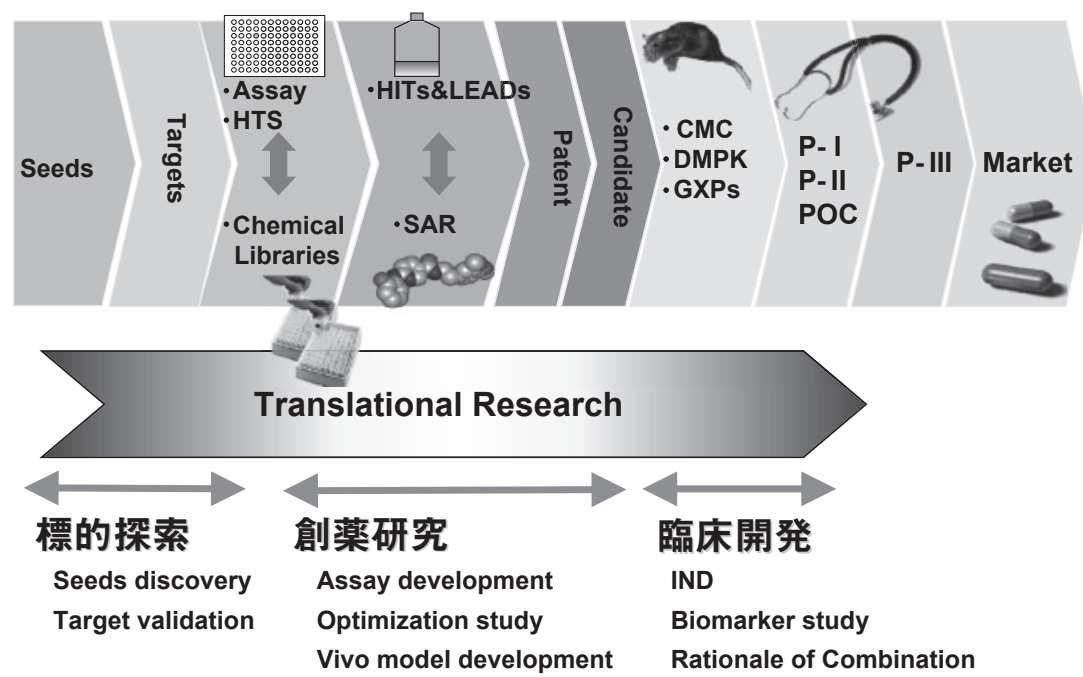

図 2 がん分子標的治療薬の創製プロセスにおけるトランスレーショナルリサーチ

れてきた。これらの新薬は，(1)標的探索プロセス（標 的分子の発見〜機能解析), (2)創薬研究プロセス (化合 物のスクリーニング〜最適化研究), (3)臨床開発プロ セス（治験申請・臨床試験〜承認申請）を経て, 臨床 での有用性が確認されて上市に至っている(図 2)。一 般的に臨床試験入りした新薬の成功確率は $10 \%$ 以下 と言われている。 今後，この成功確率を高めるため特 に「がん分子標的治療薬」の研究開発におけるトラン スレーショナルリサーチの重要性が高まっている。こ れまで, 基礎研究を臨床応用するために様々な意味の 「トランスレーショナルリサーチ（橋渡し研究）」がさ れてきているが, 報告されている例は上市まで進んだ ケースが殆どである。失敗例について積極的に公表さ れるケースは多くない.このように限られた情報しか 得られない状況であるが, 以下に各プロセスにおける トランスレーショナルリサーチの役割について筆者の 考えを示す。

\section{2）標的探索プロセス（標的分子の発見〜機能解析）}

「がん分子標的治療薬」はその名の通り, 標的分子に 対して作用して抗がん作用を示す薬として定義されて いる. 標的分子の発見と同定は, 最初の創薬プロセス であり, 創薬研究の中でも最も重要な要素の 1 つであ る（ターゲットデイスカバリー： target discovery）. 分子生物学の進展と創薬技術の進歩によって, 新規分 子標的の発見・同定が続々と報告されており, 毎週の ように一流学術誌を賑わしている.これらの標的分子 の役割を解明することから，難治性がんに対する新規 治療の概念, アプローチが提言され, 新薬の研究開発 が開始される。基礎研究で見出された標的分子の選択 と妥当性の確認という最初のプロセスである.このプ ロセスにおけるトランスレーショナルリサーチは標的 分子を対象として, 臨床サンプルを用いた発現解析, 正常組織とがん組織での発現の差, 患者での予後因子 の可能性などを検証することが，挙げられる。ささらに，
RNAi，低分子阻害薬，抗体などのツールを用いて標的 阻害に基づく抗腫瘍活性などを評価し，標的の妥当性 を検証する(ターゲットバリデーション： target validation). 3）創薬研究プロセス（化合物のスクリーニング〜最 適化研究)

妥当性が確認された標的分子への創薬アプローチは, 各製薬企業, 創薬ベンチャー, バイオベンチャー, ア カデミアによって異なるため一般化できないが, 以下 の様な代表例が挙げられる. (1)標的分子の機能を制御 するアッセイ系を構築し, 多数のライブラリー化合物 をスクリーニングしてヒット化合物（抗体や核酸を含 む) を取得. (2)得られたヒット化合物を最適化して, 標的分子を発現しているがん細胞への in vitro 作用を 検証. (3) in vivo 抗がん作用を検証するために, がん細 胞や腫瘍を移植されたマウスで抗がん作用を検証. (4) 様々なプロセスを経て選択された化合物は臨床試験へ 進める前段階の試験で, 薬理作用, 薬物動態, 安全性 を確認し, 治験薬製剂を準備して治験申請へ進める. (5)この間, 開発化合物を実業化するため特許出願し権 利を確保する(3).

このプロセスにおけるトランスレーショナルリサー チの目的は, 開発化合物の臨床効果予測の精度を高め ることである。アカデミアで構築された新規の創薬技 術を製薬企業が取り入れ, 構築された評価系やモデル を用いて完成度の高い化合物を選択する。臨床効果を 反映した良い評価系を有しているか否かで成功確率も 変わると言っても過言で無い。また，低分子創薬，抗 体医薬，ワクチンに代わりうる新たな創薬アプローチ を構築するタイプのトランスレーショナルリサーチが, 核酸医薬，細胞医薬などの新機軸の創薬を促進する可 能性が考えられる.

4）臨床開発プロセス (治験申請・臨床試験〜承認申請)

創薬研究プロセスで選択された化合物は安全性を確 認しながら臨床試験へ進む。このプロセスは, 期間と 
しては 5〜10 年以上，コストとしては 100 億円以上と 全創薬プロセスの中でも最も時間とコストを要する部 分である. そのため, このプロセスの成功確率を高め ることは医薬の生産性向上に必須であり, トランスレ ーショナルリサーチが果たす役割や意味合いも異なる. FDAが 2006 年に提唱したクリティカルパス報告 (Critical Path Report) では, 治験薬の開発を理論的, 迅速, 効率的に進めるためのツールとして「バイオマ 一カー」が必要であることが提言されている，即ち，

トランスレーショナルリサーチの 1 つとして, 治験入 りした化合物に対し感受性の高い患者を選択する「バ イオマーカー」研究が重要な役割を果たす (図 3). こ のように，バイオマーカーを用いた臨床試験の有用性 が重要な施策の 1 つとして取り上げており, トランス レーショナルリサーチへの取り組みは増えてきている.

「バイオマーカー」の例として, 薬剤の感受性や抵抗 性を規定する分子が挙げられる。たとえば, 先述の HER2 分子は抗 HER2 抗体トラスツズマブの薬効予測 バイオマーカーであり, Kras 変異は EGFR 阻害薬エル ロチニブへの抵抗性を規定することが報告されている。 有効なバイオマーカーは, 臨床試験における道先案内 人（ナビゲーター，シェルパ）を獲得したことに相当 する。治験薬（船乗り・登山者）が有能であることは 必須条件であるが, バイオマーカーの有無（有能な道 先案内人が居るか居ないか）で困難な臨床試験（航 海・登山）の成否が決まる，正しい「バイオマーカー」 を用いることにより, 各薬剤の「正しい患者」,「正し い疾患」,「正しい用量」,「正しいスケジュール」を知 って，「正しい臨床効果」を得ることが期待される (4).

\section{3. 今後の課題}

科学の進展と最新技術の普及により, 複数のがん分 子標的治療薬が登場してきた。しかしながら,これま でに承認された新薬や治療法はごく限られており, そ の恩恵を受けているがん患者数は限定されているのが 現状である，特に，進行がん患者に対して最新の標準 治療（外科的治療, 放射線治療, 抗がん薬治療）を施 しても，延命が極めて困難な状況は変っていない.こ れまでに膨大な科学的知見が積み重ねられ, さらに研 究・開発には巨大な資本が投資されているにもかかわ らず, 真の意味で延命効果を示している治療法・治療

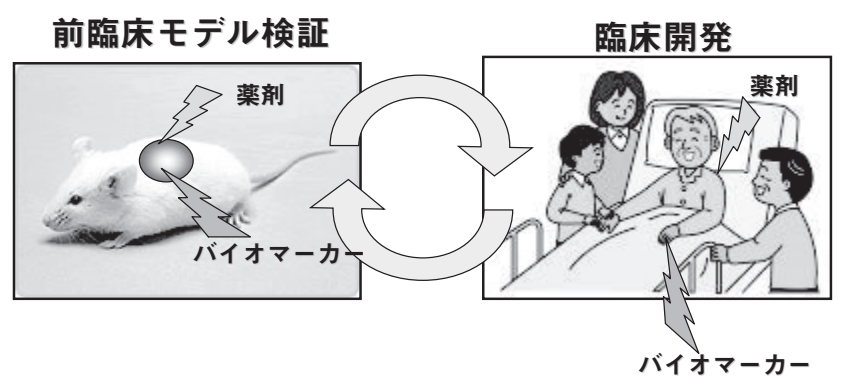

薬は少ない. 当初の期待を充足していない，あるいは 頭打ち傾向という指摘も多い. 最近では, 「2010年 7 月に公開された HER2 陰性の進行乳がん患者に対する 2 つの大規模試験 AVADO trial, RIBBON trial では, P2 試験での奏功率の改善から生存期間の延長が期待され たが, 大規模臨床試験（P3）では延命効果が確認され なかった」という VEGFに対する中和抗体の事例が挙 げられる。この類の例はこれまでも数え切れないが, 莫大な研究投資を成果として社会へ還元するための取 り組みの 1 つして, がんトランスレーショナルリサ 一チの重要性は高まっている.

前臨床モデルで有効性が確認された新規化合物が, 臨床試験で有効性が確認されない理由, 初期臨床試験 で有効性が期待された治験デザインが大規模試験で失 敗する原因については，これまでも数多く指摘されて きている. ヒトへの外挿性の課題（臨床試験入りした 化合物の完成度), 前臨床モデルの課題 (臨床腫瘍を反 映していないモデルによる化合物選択), 患者選択の 課題 (薬剤感受性のバイオマーカーが無い), 臨床評価 法の課題（代替エンドポイントの指標が必ずしも生存 延長に直結しない), 最適投与量の課題 (適切な投与量 と投与スケジュールが不明), 既存薬と併用するため の合理性（明確な根拠が無い併用試験）などである.

これらの中でも特に投資額が膨大である臨床試験段階 の課題は, 最も大きな要因となっている.

これまで述べてきたとおり，学問の進展と技術の進 歩により，がんに関わる分子が次々と明らかにされて きており，シグナル経路の阻害薬や血管新生阻害薬が 新規抗がん薬として承認されてきた. これらの新薬は 長いプロセス（標的分子の発見〜創薬研究〜臨床開 発）を経て, 臨床での有用性が確認されて上市に至っ ている。この間, 各プロセスにおけるトランスレーシ ヨナルリサーチを促進することにより，標的分子の機 能解析 · 妥当性の検証, 完成度の高い新薬の創製, バ イオマーカーを活用した上市確率の向上とコストの削 減を図ることが可能になる。医薬品開発の生産性を向 上させることを目指したトランスレーショナルリサー チへの期待は高まっている。

\section{おわりに}

医薬品開発の課題を解決するためにもトランスレー ショナルリサーチが果たす役割は多く，その重要性が 増している. 今後, 本稿で示してきた各ステップで 様々な対策・工夫を図ることにより, これまで以上に 効率的に迅速に患者に新薬を届けることが重要である.

\section{文献}

1) 人口労働統計. 厚生労働省.

2) Hanahan D, et al. Cell. 2000 Jan 7;100 (1):57-70.

3) 新臨床腫瘍学. 抗がん薬の薬理学. 南江堂; 2009. p. 266-270.

4) Human Science. がんバイオマーカー研究の現状と展望. 2008; $19(2)$. 